\title{
Variscan structural evolution of the western High Atlas and the Haouz plain (Morocco)
}

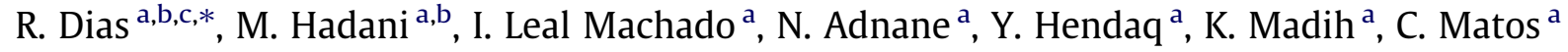 \\ a Lab. Investigação Rochas Industriais Ornamentais, Univ. Évora, Convento das Maltesas 7100-513 Estremoz, Portugal \\ b Centro Geofisica Évora, Rua Romão Ramalho, no. 59, 7000 Évora, Portugal \\ ' Dep. Geociências, Univ. Évora, Rua Romão Ramalho, no. 59, 7000 Évora, Portugal
}

\section{A R T I C L E I N F O}

\section{Article history:}

Received 14 September 2009

Received in revised form 3 July 2011

Accepted 7 July 2011

Available online $\mathrm{xxxx}$

\section{Keywords:}

Morocco

Variscan orogeny

Western High Atlas

Haouz plain

Dextral oblique collision

\begin{abstract}
A B S T R A C T
The Variscan belt is one of the major geological features of Morocco. Based on the paleogeography of the Paleozoic formations and related tectonometamorphic evolution, different domains have been proposed for this segment of the orogen. The western High Atlas is one such domain, which is usually considered as an external zone of the orogen where most of its deformation is ascribed to a first and main Variscan tectonic event $\left(D_{1}\right)$. Such a deformation has been described in previous studies that emphasize a N-S trending folds with a western vergency. These folds, having an axial plane cleavage, locally rotate in a continuous way to a NE-SW trend, becoming sub-parallel to major dextral coeval shear zones.

In this work a late $D_{1}$ stage is characterized $\left(D_{1 b}\right)$, which is restricted to the vicinity of regional scale WNW-ESE trending sinistral shear zones. The earlier structures $\left(D_{1 a}\right)$ are deflected by these shears with kinematics compatible with their sinistral displacement. The previously described Lalla Takerkoust fault in the Haouz plain and the newly proposed Adassil shear zone are ascribed to such an event.

The ENE-WSW dextral shears and the WNW-ESE sinistral ones are here considered as a kind of conjugated system during the $D_{1}$ Variscan event. However, the dextral shears not only slightly predate the onset of the sinistral shears, but they also predominate at a regional scale. Such heterogeneity could be understood by considering that the dextral family, not only is synthetic with respect to the main oblique collision between Laurentia and Gondwana that gives rise to the Variscan orogeny, but also follows previous basement anisotropies.
\end{abstract}

() 2011 Elsevier Ltd. All rights reserved.

\section{Introduction}

Although the Variscan deformation (Fig. 1A) is widespread in Morocco, the strong Alpine reworking of previous major discontinuities disrupted the original tectonic pattern (e.g. Michard et al., 2008, 2010a and cited references). Therefore, the Precambrian and Paleozoic sectors, although beautifully exposed, appear as fault bounded isolated domains in contact, with either Mesozoic major elevated blocks, or with Cenozoic wide plains. This dispersion makes it difficult to put constraints on Variscan geodynamic evolution. Detailed structural and tectonic studies in each domain are thus crucial for the understanding of this evolution.

By its geological and structural position, the Paleozoic massif of the western High Atlas constitutes a hinge between the Sahara domain in the South and the Meseta domain in the North (Piqué et al., 1990; Fig. 1B). While the upper Proterozoic/lower Paleozoic formations of the Anti-Atlas and the Cambrian successions of the coastal

* Corresponding author at: Lab. Investigação Rochas Industriais Ornamentais, Univ. Évora, Convento das Maltesas 7100-513 Estremoz, Portugal. Fax: + 351268 334285.

E-mail address: rdias@uevora.pt (R. Dias).
Meseta are well known, a synthetic view of the western High Atlas is still lacking.

Structural mapping done in five regions of the northern domains of the western High Atlas and the neighboring Haouz plain allows detailed characterization of the major tectonic events that were active during upper Paleozoic times. The strain pattern of the first and main $D_{1}$ Variscan structures (i.e. cleavage/schistosity and stretching lineation), which are coeval of the main metamorphic event, emphasized the role of map scale shears in the establishment of the orogenic framework in these domains; such a pattern is consistent from the more metamorphic domains of the western High Atlas, where the $\mathrm{D}_{1}$ foliation is a schistosity and the stretching lineation is present, to the less metamorphic Haouz plain where a $D_{1}$ cleavage is found but usually without any associated stretching lineation. While the ENE-WSW dextral shears are already well known, new data are presented which support a sinistral kinematics along WNW-ESE trends. Even if both shear families were reactivated during Alpine deformation, the interference structures show that they have, not only been developed during Variscan times, but also could be ascribed to the main tectonic event, which give rise to the Variscan pattern of this domain. 